\title{
Antioxidant vitamins in the context of nonalcoholic fatty liver disease in obese children and adolescents
}

\author{
Vitaminas antioxidantes no contexto da doença hepática gordurosa não alcoólica em crianças e \\ adolescentes obesos \\ Vitaminas antioxidantes en el contexto de la enfermedad hepática grasosa no alcohólica en niños y \\ adolescentes obesos
}

Fábio da Veiga Ued ${ }^{1}$, Virgínia Resende S. Weffort ${ }^{1}$

\section{ABSTRACT}

Objective: To review the literature on the importance of antioxidant vitamins, analyzed in the context of dietary intake, its plasma levels, and its current use as a supplementation treatment in obese children and adolescents with nonalcoholic fatty liver disease.

Data sources: The articles were identified in Lilacs, Ibecs, SciELO, PubMed/Medline, and Scopus databases. To conduct the survey, the "fatty liver" descriptor was associated to the following words: "children", "antioxidants" and "vitamins". The search was limited to articles written in Portuguese, Spanish and English, with publication date until December, 2012.

Data synthesis: Six studies were selected. The survey revealed a low dietary intake and low antioxidant vitamins serum levels in this population. The changes in lifestyle, with adequate dietary intake of vitamins, and the increase in physical activity were associated with a significant improvement in liver histology and in laboratory tests. Vitamin supplementation also improved the disease progression markers, as the alanine aminotransferase serum levels and the histological characteristics of lobular inflammation and hepatocellular damage. However, these improvements were not statistically significant in all studies.
Conclusions: There is insufficient evidence to recommend or to refute antioxidant supplementation in patients with simple steatosis or steatohepatitis. The changes in lifestyle seem to be, at the present time, the more advisable therapy.

Key-words: vitamins; fatty liver; obesity; child; adolescent.

\section{RESUMO}

Objetivo: Revisar a literatura sobre a importância das vitaminas antioxidantes, analisadas sob o contexto do consumo dietético, seus respectivos níveis plasmáticos e sua atual utilização como tratamento de suplementação em crianças e adolescentes obesos com doença hepática gordurosa não alcoólica.

Fontes de dados: Identificaram-se os artigos nas bases de dados Lilacs, Ibecs, SciELO, PubMed/MedLine e Scopus. Para realizar a pesquisa, utilizou-se o descritor "fígado gorduroso", associado aos termos "crianças", "antioxidantes" e "vitaminas". A busca limitou-se aos artigos em português, espanhol e inglês, com data limite de publicação até dezembro de 2012.

Síntese dos dados: Selecionaram-se seis estudos. A pesquisa revelou baixa ingestão dietética e baixos níveis de
Instituição: Universidade Federal do Triângulo Mineiro (UFTM), Uberaba, MG, Brasil

IUFTM, Uberaba, MG, Brasil
Endereço para correspondência:

Fábio da Veiga Ued

Avenida Getúlio Guaritá, 107 - Abadia

CEP 38025-440 - Uberaba/MG

E-mail: fabio_uftm@hotmail.com

Fonte financiadora: Coordenação de Aperfeiçoamento de Pessoal de Níve Superior (Capes)

Conflito de interesse: nada a declarar

Recebido em: 17/1/2013

Aprovado em: 15/5/2013 
concentração sérica de vitaminas antioxidantes na população estudada. A mudança nos hábitos de vida, com adequação do consumo dietético de vitaminas e aumento da atividade física, associou-se à melhora significativa na histologia hepática e nos exames laboratoriais. A suplementação vitamínica também melhorou os marcadores de progressão da doença, como os níveis séricos de alanina aminotransferase e as características histológicas de inflamação lobular e lesão hepatocelular. Contudo, essas melhorias não foram estatisticamente significativas em todos os estudos.

Conclusões: Não há evidências suficientes para recomendar ou refutar a suplementação com antioxidantes em pacientes com esteatose simples ou esteato-hepatite. A mudança no estilo de vida parece ser, no momento, a terapêutica mais aconselhável.

Palavras-chave: vitaminas; fígado gorduroso; obesidade; criança; adolescente.

\section{RESUMEN}

Objetivo: Revisar la literatura sobre la importancia de las vitaminas antioxidantes, analizadas bajo el contexto del consumo dietético, sus respectivos niveles plasmáticos y su actual utilización como tratamiento de suplementación en niños y adolescentes obesos con enfermedad hepática grasosa no alcohólica.

Fuentes de datos: Se identificaron los artículos en las bases de datos Lilacs, Ibecs, SciELO, PubMed/MedLine y Scopus. Para realizar la investigación, se utilizó el descriptor «hígado grasoso», asociado a los términos «niño», «antioxidantes»y «vitaminas». La búsqueda se limitó a los artículos en portugués, español e inglés, con fecha límite de publicación hasta diciembre de 2012.

Síntesis de los datos: Se seleccionaron seis estudios. La investigación reveló baja ingestión dietética y bajos niveles de concentración sérica de vitaminas antioxidantes en la población estudiada. El cambio en los hábitos de vida, con adecuación del consumo dietético de vitaminas y aumento de la actividad física, se asoció a la mejora significativa en la histología hepática y en los exámenes laboratoriales. La suplementación vitamínica también mejoró los marcadores de progresión de la enfermedad, como los niveles séricos de alanina aminotransferasa y las características histológicas de inflamación lobular y lesión hepatocelular. Sin embargo, esas mejorías no fueron estadísticamente significativas en todos los estudios.
Conclusiones: No hay evidencias suficientes para recomendar o rechazar la suplementación con antioxidantes en pacientes con esteatosis simple o esteato-hepatitis. El cambio en el estilo de vida parece ser, en el momento, la terapéutica más aconsejable.

Palabras clave: vitaminas; hígado grasoso; obesidad; niño; adolescente.

\section{Introduction}

The non-alcoholic fatty liver disease (NAFLD) is characterized by histopathological findings compatible with alcoholic liver disease in individuals with no history of significant consumption of alcohol, but with different clinical and epidemiological profile ${ }^{(1)}$. In general, it is assumed that there are several causes associated with NAFLD. Secondary causes are related to patients with metabolic diseases or the use of specific drugs. However, the primary cause is obesity and its comorbidities ${ }^{(2)}$. The alarming increase in the prevalence rates of overweight and obesity may explain the emergence of the NAFLD as the leading cause of liver disease in the pediatric population worldwide ${ }^{(3)}$.

In Brazil, over the past decades, the prevalence of overweight and obesity in children and adolescents is increasing. In 2008, $33.5 \%$ of children aged from 5 to 9 years were overweight. In adolescents from 10 to 19 years, the prevalence of excess weight was of $20.5 \%{ }^{(4)}$. Still, the real prevalence of NAFLD in the pediatric population is still unknown. Recent data refer to a range of prevalence from 3.0 to $60.3 \%$ in obese children and adolescents ${ }^{(5)}$.

As a result of obesity, NAFLD can relate strongly with insulin resistance, type 2 diabetes, hypertension, dyslipidemia, and components associated with the metabolic syndrome $^{(6)}$. Furthermore, some of these are predictive factors for cardiovascular disease, which demonstrates the importance of monitoring the disease in pediatric patients to establish interventions to reduce the risks inherent to associated comorbidities $^{(7)}$.

It is a progressive disease and potentially lethal, recognized in pediatric patients. It includes a spectrum of clinicopathologic entities, from simple steatosis, progressing to non-alcoholic steatohepatitis (NASH) and, eventually to cirrhosis, end-stage liver disease, with chronic and irreversible inflammation ${ }^{(8)}$.

According to the consensus published by the European Society for Paediatric Gastroenterology, Hepatology and 
Nutrition (ESPGHAN) in 2012, the definitions of clinicopathologic steatosis are ${ }^{(9)}$ :

- NAFLD: is the most benign simple steatosis, with mild inflammation, or short term for the entire spectrum of the disease.

- NASH: in Pediatrics, is a hepatocellular macrovesicular steatosis with portal inflammation, with or without portal fibrosis in the absence of ballooning degeneration and perisinusoidal fibrosis.

- Cirrhosis: is the most advanced stage of fibrosis (stage 3 - extended fibrosis over adjacent portals, bridging fibrosis, stage 4 - cirrhosis with loss of the normal structure of the liver).

To describe the survival of children with NAFLD, a followup study of 20 years was conducted. The study shows that in children the disease is potentially progressive and some showed evolution of steatosis to steatohepatitis, combined with fibrosis and advanced cirrhosis, reaching the final stage of the disease with the consequent need for liver transplantation. The research shows that NAFLD in children is associated with a significantly decreased survival in the long term in relation to the expected survival for the general population of the same age and sex. Children with NAFLD had 13.8 times greater risk of death or need for a liver transplant than the general population of the same age and $\operatorname{sex}^{(10)}$.

The distinction between simple steatosis and NASH can only be made, at the moment, by liver biopsy, the gold standard for the diagnosis of NAFLD. Despite ongoing research, the pathophysiological mechanism of NAFLD is still poorly defined. Currently, one theory suggests that the installation process of the disease occurs in two stages ${ }^{(11)}$. The first relates to the absorption disorders in the synthesis and degradation of fatty acid secretion by the liver, resulting in macrovesicular steatosis. This results from the increased hepatic synthesis and esterification of fatty acids to triglycerides and triglyceride decrease of the transport out of the liver. There would be, therefore, a deviation of the mechanisms of lipolysis in favor of lipogenesis ${ }^{(12)}$. The second stage is characterized by the damage caused by the liver changes, resulting in oxidative stress, whose final process of lipid peroxidation is responsible for the expression of cytokines, including tumor necrosis factor alpha (TNF- $\alpha$ ), resulting in activity and inflammatory disease progression ${ }^{(12)}$.

There is no consensus for the treatment of NAFLD. However, preventing cirrhosis and retarding the progression or reverting fibrosis become major objectives of the treatment. Interventions may involve changes in lifestyle and pharmacotherapy. Most studies aimed at treating NAFLD using diet and exercise, insulin-sensitizing agents, antagonists of TNF- $\alpha$ or even antioxidants ${ }^{(13,14)}$.

Studies of antioxidant therapy have aroused enthusiasm at the possibility of treating the disease. Liver diseases, especially those involving inflammatory process, result in oxidative stress. The non-enzymatic electron receptors, substances able to fight oxidation (antioxidant), vitamins $\mathrm{E}$ and $\mathrm{C}$, may play an important role in protecting the cell membrane, inhibiting the propagation of lipid peroxidation caused by free radicals and the progression of simple steatosis to steatohepatitis ${ }^{(15)}$.

Although the mechanisms of interaction between the compounds are not well established, it is known that patients with NASH present higher levels of oxidative stress markers, compared with those with simple steatosis ${ }^{(16)}$, and may have decreased plasma and antioxidants levels when compared with healthy control groups ${ }^{(17)}$. The reasons can be the depletion of antioxidants, in order to counteract oxidative stress, or poor oral intake of food sources, which suggests antioxidant therapy as a rational treatment ${ }^{(17)}$.

A healthy and balanced meal consists of food sources of vitamins with antioxidant properties, such as vitamins A, $\mathrm{C}$, and E. Among the benefits of these compounds, it is emphasized that the antioxidant activity of carotenoids is responsible, in part, for its protective role against cardiovascular diseases and cancers ${ }^{(18)}$; vitamin $\mathrm{E}$, also found in plasma and particle of low density lipoprotein (LDL), plays a protective role before lipid oxidation, and vitamin $C$ is able to participate in the regeneration system of vitamin $\mathrm{E}$, as well as maintaining the antioxidant potential of plasma ${ }^{(19)}$.

The present study is a report of information through review of scientific articles. The following topics were analyzed: The importance of antioxidant vitamins and their relation to dietary intake, their plasma levels and their current use as a treatment through supplementation in obese children and adolescents with NAFLD.

\section{Method}

Articles were identified by searching the databases Lilacs, Ibecs, SciELO, PubMed and Scopus, using the descriptor "fígado gorduroso" ("fatty liver"), associated with the descriptors "crianças" ("children"), "antioxidantes" ("antioxidant") and "vitaminas" ("vitamins"). The search was limited to articles written in Portuguese, Spanish, and English with date of publication until December 2012. 
The following inclusion criteria were established: research conducted with both sexes, children and adolescents up to 19 years old; confirmed diagnosis of NAFLD, identified by liver biopsy, ultrasonography (USG), magnetic resonance imaging or alteration of alanine aminotransferase (ALT) levels; and antioxidant vitamins approach in prevention and/or treatment. The following articles were not analyzed: articles that presented data from animal models, adult populations, articles not available in full, and samples with subjects with other diseases than obesity as a cause of NAFLD.

The results of the searches were screened by two qualified researchers, from the titles and abstracts of articles. After the identification of relevant studies, the full publication was obtained and reviewed by two professionals, in order to determine eligibility for final inclusion.

Complementing the search in the databases, the reference lists of included articles were consulted to identify relevant studies not identified in the previous stage of the research.
In total, six studies were selected based on inclusion criteria. The developed studies had their experimental protocols approved by the Research Ethics Committee of the respective institutions.

As this is a review and update on the subject, the present study was not submitted to the Research Ethics Committee.

\section{Results}

The selected studies linking NAFDL to antioxidant vitamins in the outcome are summarized in Chart 1.

Nobili et $a^{(20)}$ analyzed the effect of vitamin E supplementation (600UI/day) on liver functions and on insulin resistance, comparing the group with children who had only changed their dietary habits. All children were diagnosed with biopsy-proven NAFLD. Patients underwent a program of nutritional guidance, besides daily physical exercise. Ninety children and adolescents from 3 to 18 years old were

Chart 1 - Description of the studies included in the review: the relationship between. Nonalcoholic fatty liver disease and antioxidant vitamins

\begin{tabular}{|c|c|c|c|c|c|c|}
\hline $\begin{array}{l}\text { Author/ years of } \\
\text { publication/ Place }\end{array}$ & Type of study & Sample & $\begin{array}{c}\text { Vitamin } \\
\text { Analyzed }\end{array}$ & Results & Conclusion & $\begin{array}{c}\text { Statistical } \\
\text { Analysis }\end{array}$ \\
\hline $\begin{array}{l}\text { Nobili et } a^{(20)} 2006 \\
\text { Italy }\end{array}$ & Double-blind & $\mathrm{n}=90$ & $\begin{array}{l}\text { Vitamins } E \\
\text { and } C\end{array}$ & $\begin{array}{c}\text { Vitamin } \\
\text { supplementation } \\
\text { with expected effect } \\
\text { Intervention in } \\
\text { lifestyle with the } \\
\text { expected effect }\end{array}$ & $\begin{array}{c}\text { There was } \\
\text { no statistical } \\
\text { difference between } \\
\text { supplementation } \\
\text { and intervention in } \\
\text { lifestyle }\end{array}$ & $p>0.05$ \\
\hline $\begin{array}{l}\text { Nobili et } a)^{(21)} 2008 \\
\text { Italy }\end{array}$ & Double-blind & $n=53$ & $\begin{array}{l}\text { Vitamins } \mathrm{E} \\
\text { and } \mathrm{C}\end{array}$ & $\begin{array}{c}\text { Vitamin } \\
\text { supplementation } \\
\text { with expected effect } \\
\text { Intervention in } \\
\text { lifestyle with the } \\
\text { expected effect }\end{array}$ & $\begin{array}{c}\text { There was } \\
\text { no statistical } \\
\text { difference between } \\
\text { supplementation } \\
\text { and intervention in } \\
\text { lifestyle }\end{array}$ & $p>0.05$ \\
\hline $\begin{array}{l}\text { Souza et al(22) } 2008 \\
\text { Brazil }\end{array}$ & Cross-sectional & $n=46$ & Vitamin A & $\begin{array}{l}\text { Reduced retinol } \\
\text { serum levels }\end{array}$ & $\begin{array}{l}\text { There was no } \\
\text { association with the } \\
\text { presence of NAFLD }\end{array}$ & $p>0.05$ \\
\hline $\begin{array}{l}\text { Mager et al(23) } 2010 \\
\text { Canada }\end{array}$ & Cross-sectional & $n=38$ & $\begin{array}{l}\text { Vitamins A, } \\
\text { E and C }\end{array}$ & $\begin{array}{l}\text { Inadequate intake } \\
\text { of Vit. } E \text { in the diet }\end{array}$ & $\begin{array}{l}\text { There was } \\
\text { association with the } \\
\text { presence of NAFLD }\end{array}$ & $p<0.05$ \\
\hline $\begin{array}{l}\text { Vos et a/(24) } 2011 \\
\text { United States }\end{array}$ & Cross-sectional & $n=149$ & $\begin{array}{l}\text { Vitamins } A \text {, } \\
E, C \text { and } D\end{array}$ & $\begin{array}{l}\text { Inadequate intake } \\
\text { of Vit. } E \text { in the diet }\end{array}$ & $\begin{array}{l}\text { Correlation with the } \\
\text { degree of steatosis }\end{array}$ & $p<0.05$ \\
\hline $\begin{array}{l}\text { Lavine et } a^{(25)} 2011 \\
\text { United States }\end{array}$ & Double-blind & $n=173$ & Vitamin E & $\begin{array}{c}\text { Vitamin } \\
\text { supplementation } \\
\text { without expected } \\
\text { effect }\end{array}$ & $\begin{array}{l}\text { There was } \\
\text { no statistical } \\
\text { difference between } \\
\text { supplementation with } \\
\text { Vit. E, metformin, } \\
\text { and placebo }\end{array}$ & $p>0.05$ \\
\hline
\end{tabular}

NAFLD: Nonalcoholic fatty liver disease; Vit.: vitamin 
followed for 12 months of treatment. The control group $(n=43)$ received placebo and nutritional counseling, while the treated group $(n=45)$ received, besides nutritional monitoring, supplementation with vitamins $\mathrm{E}$ and $\mathrm{C}(500 \mathrm{mg} / \mathrm{day})$ since the last regeneration increases oxidized vitamin $\mathrm{E}$.

At the end of the 12th month of treatment, weight loss and reduced levels of ALT, aspartate aminotransferase (AST), gamma-glutamyl transpeptidase $(\gamma-G T)$, and resistance to insulin were statistically significant in all children. Despite the improvement in the levels of biochemical markers of liver function and insulin sensitivity was more evident in the treated group, statistical significance between groups was not achieved.

In subjects who lost more than $1 \mathrm{~kg}$ in weight, regardless of the group, the reduction of ALT levels and insulin resistance were even more significant. However, supplementation of vitamins $\mathrm{E}$ and $\mathrm{C}$ for patients who already adopt a healthy lifestyle does not seem to add any significant effect ${ }^{(20)}$.

To continue the study of 12-month intervention in lifestyle ${ }^{(20)}$, Nobili et al ${ }^{(21)}$, in another study, extended the research for another 12 months and evaluated the possible histological changes upon repeated liver biopsy at 24 months. As in the first study, the intervention consisted on adjusting the diet to the caloric needs of each individual, as well as providing increased physical activity to all patients. Among the 90 children assessed previously ${ }^{(20)}$, 53 agreed to continue for another 12 months of intervention. Thus, 53 patients aged from 6 to 19 years were randomly distributed in the Placebo Group $(\mathrm{n}=28)$ and the Treated Group ( $\mathrm{n}=25$ ) who received alpha-tocopherol (600UI/day) and ascorbic acid (500mg/day). The patients were submitted to nutritional counseling monthly during the treatment period of 24 months, besides being included in an aerobic exercise program of $45 \mathrm{~min} /$ day. A multidisciplinary team with nutritionists, hepatologists, endocrinologists, psychologists, and cardiologists assessed and followed the patients.

The lifestyle intervention was associated with reduced body weight, the significant improvement in the degree of steatosis, lobular inflammation reduction and reduced activity index of NAFLD in both groups. The levels of aminotransferases, triglycerides, fasting glucose, cholesterol, and indexes of insulin resistance, improved significantly. However, improvement in all these parameters was not statistically different between the two groups.

According to the authors, nutritional education favored the higher consumption of fruits and vegetables, which may have increased the intake of natural antioxidants in both groups and minimized the effects of vitamin supplement in the group receiving the treatment. In addition, all patients underwent dietary interventions combined with increased physical activity. Thus, it is not clear whether the alpha-tocopherol and ascorbic acid would be the best intervention on NAFLD in any patients or if they would be effective only in those patients who do not adhere to the improvement in lifestyl ${ }^{(21)}$.

Souza et $a^{(22)}$ evaluated the serum retinol levels and the associated risk of developing NAFLD. Children from 6 to 10 years with low socioeconomic status were divided into two groups: 46 in the group with overweight/obesity and 45 in the control group. At ultrasound examination, there was mild or moderate steatosis in $56.5 \%$ of the group with overweight/obesity and $48.9 \%$ in the control group. Biochemical tests were performed to determine the serum retinol levels, lipid profile, and insulin resistance.

According to the authors, the high presence of steatosis in the control group comes from the peculiar characteristics of the studied population, i.e., low-income children possibly suffering from nutritional disorders associated with poor nutrition and micronutrient deficiency.

Results from insulin resistance and markers of lipid peroxidation were not significantly associated with the risk of steatosis. The reduction of serum retinol, in turn, suggested a trend of association with the presence of steatosis, but without statistical significance. Some factors may explain this reduction in plasma levels, such as low dietary intake or the fact that the disease itself requires greater mobilization of micronutrients for antioxidant defense ${ }^{(22)}$.

To evaluate lifestyles, such as habitual diet, physical activity, and energy expenditure, Mager et al ${ }^{(23)}$ conducted a study with 38 patients from 5 to 19 years with diagnosis of obesity and NAFDL, detected by ultrasonography. The study assessed body composition, waist circumference, and food intake, and laboratory exams analyzed metabolic changes.

From the homeostatic model, it was found insulin resistance in 21 patients; there were also high levels of alanine aminotransferase $(n=28)$, fasting hyperinsulinemia $(n=15)$ and hypertriglyceridemia $(n=14)$. Inflammatory markers such as TNF- $\alpha$ also showed elevated levels. As for the dosage of vitamins $A$ and $E$, plasma levels were normal.

Dietary intake was assessed by a Food Record of 3 days, including one day during the weekend. After the analysis, we observed reduced consumption of fibers, polyunsaturated fatty acids, omega 3 , and vitamin E. 
Vitamins $\mathrm{A}$ and $\mathrm{C}$ and omega 6 presented adequate intake. Saturated fatty acids and carbohydrates (sucrose and fructose), in turn, showed a higher level of consumption. The high rate of fructose intake was statistically related to lower levels of adiponectin and higher levels of TNF- $\alpha$.

Regarding physical activity, more than $65 \%$ of the time devoted to leisure was taken with sedentary activities, such as watching television, playing video games, or using the computer, which shows the contribution of lifestyle to the risk of liver damage ${ }^{(23)}$.

In the study by Vos $e t a^{(24)}$, the consumption of vitamin E through diet correlated with histopathological changes of NAFLD. They selected 149 patients from 6 to 17 years diagnosed with NAFLD confirmed by biopsy. Dietary information was obtained through a questionnaire developed by the National Health and Nutrition Examination Survey (NHANES), containing 77 items, whose image of the size of the portions was provided to improve the quantification of nutrient intake. The subjects were grouped based on the presence or absence of NASH, in four groups, according to the degree of evolution of the disease (from simple steatosis to portal and lobular inflammation).

There was no significant difference between the groups for the consumption of carbohydrates, lipids, and proteins. The groups with NASH and simple steatosis reported similar consumption of lipids, carbohydrates, antioxidants, and other micronutrients.

There was a higher consumption than the recommended daily allowance (RDA) of vitamins C, A, and D. However, the groups consumed lower quantities than those stipulated for RDA regarding folate $(400 \mathrm{mg} / \mathrm{day})$ and less than half the RDA regarding vitamin $\mathrm{E}(22,5 \mathrm{UI} /$ day).

Comparing the levels of vitamin $\mathrm{E}$ intake with the degree of evolution of the disease, it was shown that the lower the consumption, the higher the degree of development of steatosis $^{(24)}$.

A randomized, double-blind study ${ }^{(25)}$, conducted in 10 university centers of clinical research, with 173 patients from 8 to 17 years, with confirmed biopsy for NAFLD, was conducted to test whether treatment with metformin, an insulin sensitizer, or vitamin E, a natural antioxidant, would bring improvements to the biochemical and histological characteristics of children with the disease.

Participants were divided into three groups, followed for 96 weeks of treatment. Group 1 received oral metformin $(500 \mathrm{mg}$, twice a day) and vitamin E-placebo twice a day; group 2 received vitamin E (400UI, twice a day) and metformin-placebo; group 3 received vitamin E-placebo and metformin-placebo, twice a day.

The reduction in ALT levels was similar to placebo, both in the group treated with vitamin $\mathrm{E}$ and in the group treated with metformin. The serum triglycerides and total cholesterol levels increased, low-density lipoprotein and high-density lipoprotein decreased in all groups. These changes were not statistically significant between the groups treated with vitamin E or metformin against placebo. Still compared with placebo, no therapy demonstrated significant improvements in histological characteristics, with the exception of hepatocellular ballooning, which was reduced in the group treated with vitamin $\mathrm{E}$. The proportion of treatment effectiveness among children with NAFLD was $28 \%$ in the placebo group versus $58 \%$ in the group with vitamin $\mathrm{E}$, and $41 \%$ in the group receiving metformin ${ }^{(25)}$.

\section{Discussion}

Life habits are strongly associated to the success or failure of the treatment of obese children and adolescents diagnosed with DHGNA, which reinforces the need to adopt healthy lifestyles before the obesity epidemic in this century ${ }^{(26)}$. As for eating patterns, the study of Mager $e t$ al ${ }^{(23)}$ found high consumption of foods rich in saturated fatty acids and carbohydrates such as sucrose and fructose in the diet of children and adolescents with NAFLD. Several changes in food consumption occurred in recent years, with a predominance of hypercaloric diets. There is an indiscriminate consumption of carbohydrates and total fat, besides the excessive addition of these ingredients in processed products ${ }^{(27)}$.

In reviewing Zelberg-Sagi ${ }^{(28)}$, data regarding the association between dietary intake and NAFLD, emphasizing clearly that "quality food can be a good medicine". Some dietary interventions reported in the study, which seem beneficial in NAFLD are: 1) nutritional counseling by a multidisciplinary team, including a nutritionist, psychologist and supervisor of physical activity (to assess educational behavior and motivational therapy); 2) aerobic exercise (walking 30 minutes daily, 3 times a week); 3) restriction of calorie intake to less than $30 \mathrm{kcal} / \mathrm{kg}$ per day, with a balanced diet including low levels of saturated fats and simple sugars; 4) gradual weight loss (10\% in 6 months); 5 ) avoid rapid weight loss (more than $1.6 \mathrm{~kg} /$ week), as this may increase the progression of NAFLD; 6) monitor comorbidities, such as diabetes, obesity, and metabolic syndrome; 7) avoid sweetened foods such as soft drinks, and the consumption of trans fats and processed 
foods from fast foods; 8) the consumption of vitamin $\mathrm{E}$ (400-800UI/day) and D (1.000UI/day), ômega-3 (1g/day), and ômega-9 (olive oil) are recommended.

Children and adolescents with NAFLD presented a deficit in the intake of vitamin $\mathrm{E}^{(23,24)}$. The consumption of vitamins $A$ and $C^{(23,24)}$ was adequate, although the serum retinol levels were decreased $^{(22)}$. In the last decade, there were many efforts to improve liver damage in NAFLD. However, the results for supplementation of antioxidant vitamins are still controversial $^{(29,30)}$. While some authors ${ }^{(20,21)}$ have found benefits in the supplementation of vitamins $\mathrm{E}$ and $\mathrm{C}$, others did not obtain similar results.

The study conducted with children and adolescents ${ }^{(25)} \mathrm{did}$ not find the expected positive effects of supplementation with vitamin $\mathrm{E}$ (although it has improved the process of hepatocyte ballooning), compared to metformin or placebo. Therefore, one should be careful at concluding that the treatment with metformin is better than the dietary prescription or the treatment with vitamin $\mathrm{E}^{(31)}$.

Faced with this scenario, some researches also sought to evaluate the benefits of antioxidant therapy, demonstrating the effectiveness of the combination of vitamins $\mathrm{E}$ and $\mathrm{C}$ in the treatment to reduce the scale of fibrosis ${ }^{(32)}$ and ALT

\section{References}

1. Lewis JR, Mohanty SR. Nonalcoholic fatty liver disease: a review and update. Dig Dis Sci 2010;55:560-78.

2. Kneeman JM, Misdraji J, Corey KE. Secondary causes of nonalcoholic fatty liver disease. Therap Adv Gastroenterol 2012;5:199-207.

3. Barshop NJ, Sirlin CB, Schwimmer JB, Lavine JE. Review article: epidemiology, pathogenesis and potential treatments of paediatric non-alcoholic fatty liver disease. Aliment Pharmacol Ther 2008;28:13-24.

4. Brasil - Instituto Brasileiro de Geografia e Estatística [homepage on the Internet]. Pesquisa de orçamentos familiares 2008-2009: despesas, rendimentos e condições de vida [cited 2012 Jun 05]. Available from: http:// www.ibge.gov.br/home/estatistica/populacao/condicaodevida/pof/2008_2009/ POFpublicacao.pdf

5. Padilha PC, Rocha HF, Alves N, Peres WA. Prevalence of nonalcoholic fatty liver disease in obese children and adolescentes: a systematic review. Rev Paul Pediatr 2010;28:387-93.

6. Manco M, Marcellini M, Devito R, Comparcola D, Sartorelli MR, Nobili V. Metabolic syndrome and liver histology in paediatric non-alcoholic steatohepatitis. Int J Obes (Lond) 2008;32:381-7.

7. Pacifico L, Nobili V, Anania C, Verdecchia P, Chiesa C. Pediatric nonalcoholic fatty liver disease, metabolic syndrome and cardiovascular risk. World J Gastroenterol 2011;17:3082-91.

8. Papandreou D, Rousso I, Mavromichalis I. Update on non-alcoholic fatty liver disease in children. Clin Nutr 2007;26:409-15.

9. Vajro P, Lenta S, Socha P, Dhawan A, McKiernan P, Baumann U et al. Diagnosis of nonalcoholic fatty liver disease in children and adolescents: position paper of the ESPGHAN Hepatology Committee. J Pediatr Gastroenterol Nutr 2012;54:700-13. levels in adults ${ }^{(33)}$, and efficacy of pharmacological treatment combined with changes in lifestyle in children ${ }^{(34)}$.

It may be concluded that few studies have analyzed the treatment and/or prevention of NAFLD with antioxidant vitamins, especially in pediatric patients. The results show that there is insufficient evidence to recommend or refute antioxidant supplements in patients with steatohepatitis or NASH.

The change in lifestyle, with an adequate diet and increased physical activity, was associated with a significant improvement in liver histology and laboratory tests of pediatric DHGNA. Supplementation with alpha-tocopherol and ascorbic acid, in turn, cannot be associated with a greater beneficial effect compared to the effect achieved only by the change in lifestyle.

However, it was observed that the antioxidant vitamins, present in the diet or administered as a supplement, still require further evaluation to assess the beneficial or detrimental effects in NAFLD and in EHNA.

Randomized clinical trials - with a larger sample size, including a well-defined type of antioxidant supplements offered for long periods of time and compared to placebo are perhaps the ideal model for future research.
10. Feldstein AE, Charatcharoenwitthaya P, Treeprasertsuk S, Benson JT, Enders FB, Angulo P. The natural history of nonalcoholic fatty liver disease in children: a follow-up study for up to 20-years. Gut 2009;58:1538-44.

11. Martel C, Esposti DD, Bouchet A, Brenner C, Lemoine A. Nonalcoholic steatohepatitis: new insights from OMICS studies. Curr Pharm Biotechnol 2012;13:726-35.

12. Reid AE. Nonalcoholic steatohepatitis and focal fatty liver. In: Feldman M, Friedman LS, Brandt LJ, editors. Sleisenger and Fordtran's gastrointestinal and liver disease. $9^{\text {th }}$ ed. Philadelphia: Saunders; 2010.

13. Satapathy SK, Sanyal AJ. Novel treatment modalities for nonalcoholic steatohepatitis. Trends Endocrinol Metab 2010;21:668-75.

14. Barshop NJ, Sirlin CB, Schwimmer JB, Lavine JE. Review article: epidemiology, pathogenesis and potential treatments of paediatric non-alcoholic fatty liver disease. Aliment Pharmacol Ther 2008;28:13-24.

15. Singal AK, Jampana SC, Weinman SA. Antioxidants as therapeutic agents for liver disease. Liver Int 2011;31:1432-48.

16. Machado MV, Ravasco P, Jesus L, Marques-Vidal P, Oliveira CR, Proença T et al. Blood oxidative stress markers in non-alcoholic steatohepatitis and how it correlates with diet. Scand J Gastroenterol 2008;43:95-102.

17. Erhardt A, Stahl W, Sies H, Lirussi F, Donner A, Häussinger D. Plasma levels of vitamin $E$ and carotenoids are decreased in patients with Nonalcoholic Steatohepatitis (NASH). Eur J Med Res 2011;16:76-8.

18. McNulty H, Jacob RF, Mason RP. Biologic activity of carotenoids related to distinct membrane physicochemical interactions. Am J Cardiol 2008;101:20D-9.

19. Nwose EU, Jelinek HF, Richards RS, Kerr PG. The "vitamin E regeneration system" (VERS) and an algorithm to justify antioxidant supplementation in diabetes - a hypothesis. Med Hypotheses 2008;70:1002-8. 
20. Nobili V, Manco M, Devito R, Ciampalini P, Piemonte F, Marcellini M. Effect of vitamin $\mathrm{E}$ on aminotransferase levels and insulin resistance in children with non-alcoholic fatty liver disease. Aliment Pharmacol Ther 2006;24:1553-61.

21. Nobili V, Manco M, Devito R, Di Ciommo V, Comparcola D, Sartorelli MR et al. Lifestyle intervention and antioxidant therapy in children with nonalcoholic fatty liver disease: a randomized,controlled trial. Hepatology 2008;48:119-28.

22. Souza FI, Amancio OM, Sarni RO, Pitta TS, Fernandes AP, Fonseca FL et al. Non-alcoholic fatty liver disease in overweight children and its relationship with retinol serum levels. Int J Vitam Nutr Res 2008; 78:27-32.

23. Mager DR, Patterson C, So S, Rogenstein CD, Wykes LJ, Roberts EA. Dietary and physical activity patterns in children with fatty liver. Eur J Clin Nutr 2010;64:628-35.

24. Vos MB, Colvin R, Belt P, Molleston JP, Murray KF, Rosenthal $\mathrm{P}$ et al. Correlation of vitamin E, uric acid, and diet composition with histologic features of pediatric NAFLD. J Pediatr Gastroenterol Nutr 2012;54:90-6.

25. Lavine JE, Schwimmer JB, Van Natta ML, Molleston JP, Murray KF, Rosenthal $P$ et al. Effect of vitamin $E$ or metformin for treatment of nonalcoholic fatty liver disease in children and adolescents: the TONIC randomized controlled trial. JAMA 2011;305:1659-68.
26. Nobili V, Marcellini M, Devito R, Ciampalini P, Piemonte F, Comparcola D et al. NAFLD in children: a prospective clinical-pathological study and effect of lifestyle advice. Hepatology 2006;44:458-65.

27. Tappy L, Lê KA, Tran C, Paquot N. Fructose and metabolic diseases: new findings, new questions. Nutrition 2010;26:1044-9.

28. Zelber-Sagi S, Ratziu V, Oren R. Nutrition and physical activity in NAFLD: an overview of the epidemiological evidence. World J Gastroenterol 2011;17:3377-89.

29. Adams LA, Angulo P. Vitamins $E$ and $C$ for the treatment of NASH duplication of results but lack of demonstration of efficacy. Am J Gastroenterol 2003;98:2348-50.

30. Harrison SA, Ward JA, Schenker S. The role of vitamin E and C therapy in NASH. Am J Gastroenterol 2004;99:1862.

31. Kadayifci A, Merriman RB. Metformin, vitamin E, and diet for patients with nonalcoholic fatty liver disease. Am J Gastroenterol 2006;101:1396.

32. Harrison SA, Torgerson S, Hayashi P, Ward J, Schenker S. Vitamin E and vitamin $\mathrm{C}$ treatment improves fibrosis in patients with nonalcoholic steatohepatisis. Am J Gastroenterol 2003;98:2485-90.

33. Ersöz G, Günşar F, Karasu Z, Akay S, Batur Y, Akarca US. Management of fatty liver disease with vitamin $E$ and $C$ compared to ursodeoxycholic acid treatment. Turk J Gastroenterol 2005;16:124-8.

34. Alisi A, Nobili V. Non-alcoholic fatty liver disease in children now: lifestyle changes and pharmacologic treatments. Nutrition 2012;28:722-6. 